\title{
Retirement Reconsidered: Labor Force Participation of Older Men in the United States
}

\author{
Joseph S. Falzone ${ }^{1}$ \\ ${ }^{1}$ Peirce College, Philadelphia, Pennsylvania, USA \\ Correspondence: Joseph S. Falzone, 225 Port-Royal Avenue, Philadelphia, PA, 19128, USA. Tel: \\ 1-215-487-2682. E-mail: beloquinta@comcast.net
}

Received: March 7, 2016

Accepted: March 30, 2016

Online Published: April 28, 2016

doi:10.5539/res.v8n2p201

URL: http://dx.doi.org/10.5539/res.v8n2p201

\begin{abstract}
The objectives of this article are two fold. Changes in older men's labor force participation in the United States are first described focusing on human capital and demographic variables. A model of the labor/leisure choice and the retirement decision of older men are then estimated employing Maximum Likelihood Probit. While changes in Social Security Benefit rules are a significant factor in explaining the trend of rising retirement age among older men, the focus here is on additional factors that contribute to older men's decision to forestall retirement. Probit coefficient estimates for three distinct age cohorts verify the effects of hypothesized determinants of the decision to retire. Specifically, the coefficient on estimated earnings is negative and has the largest marginal effect on the decision to retire followed by years of education and retired wife. The effects of wives' retirement decision will likely influence and forestall the retirement decision of married men as more working women reach retirement age. The rise in labor force participation rates of older men may offset rather than reverse the decline in men's labor force participation rates that began more than a half century ago.
\end{abstract}

Keywords: labor force participation, labor/leisure choice, labor market, retirement decision

\section{Introduction}

Beginning in the mid-1990s the labor force participation retain the United States of men 55years of age and older began to rise, continuing for almost two decades into the early 2010s (Note 1). This represents a reversal of a 100 -year trend, with the greatest declines occurring during the latter half of the $20^{\text {th }}$ century.

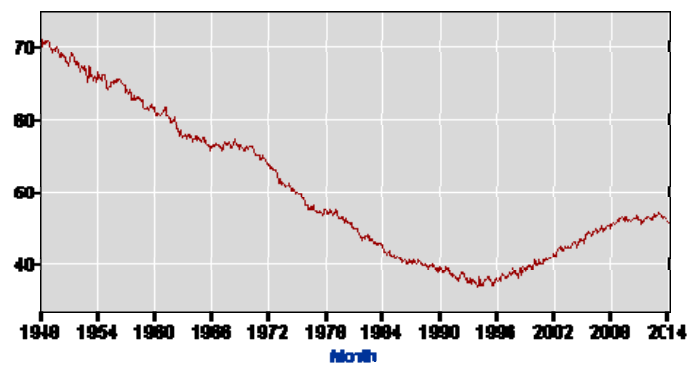

Figure 1. Labor force participation rate 1948-2014 men: 55 years and older

Current population survey: bureau of labor statistics.

The rising labor force participation rate of older men represents an anomaly from its historic trend when viewed from the perspective of major demographic and structural changes that occurred in the labor market during the $20^{\text {th }}$ century (Aaronson et al., 2006). While the labor force participation rate of all men, 16 years and older, peaked at 87 percent in 1948, that of the general population rose more than 8 percent between 1948 and the early 2000s with the greatest increase occurring between the mid-1970s and 1990s due in part to the entrance of married women into the labor force (Note 2). 


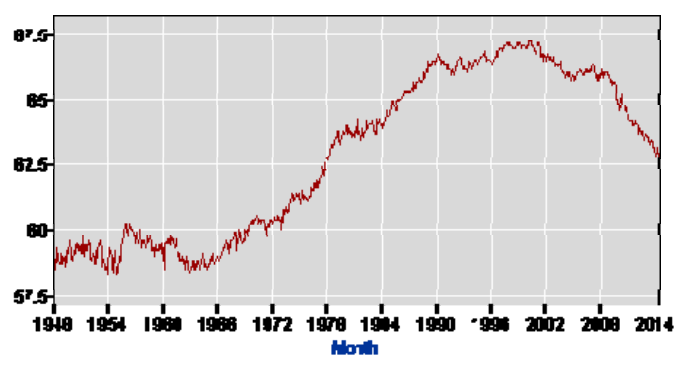

Figure 2. Labor force participation rate 1948-2014: all workers 16 years and older

Current population survey: bureau of labor statistics.

The impetus for older men's earlier withdraw from the labor force began early in the $20^{\text {th }}$ century, even before the advent of Social Security in the mid-1930s. Their withdraw can be attributed, in part, to the "wealth effect" associated with rising real lifetime income and with the concomitant rise in the demand for "leisure" (assumed here to be a normal good). Other factors contributing to the decline in the labor force participation of older men include changes in the availability of private pension plans, the availability of more advantageous health plans for retirees, more generous Social Security benefits beginning in the 1970s, and the expansion of disability insurance (Note 3). As the labor force participation rate for men began to decline by the latter-1990s, the labor force participation rate of older men declined to its lowest level, 37 percent, in the mid-1990s. Nonetheless, the rate for men 65 through 69 years of age increased 12 percent between 1984 and 2013. Bureau of Labor Statistics (BLS) beginning in 2001 the largest portion of the labor force, the so called "Baby Boomers", those born between the years 1946 and 1964, began to move into age cohorts that typically display lower labor force participation. Data from the U.S. Department of Labor show the median age of the labor force rose by almost 5 years (13 percent) between 1992 (37.1 years) and 2012 (41.9 years). The Bureau of Labor Statistics projects the median age of the labor force in the United States will increase to 42.6 years by 2022 and the percent of those over the age of 65 is expected to increase from 18 percent in 2010 to 23 percent in 2050 . The aging of the labor force, compounded by the withdraw from the labor force of prime age men, that is those aged 25 to 54 years, that began in the mid-1990s will likely place further downward pressure on aggregate labor force participation and is not without consequence.

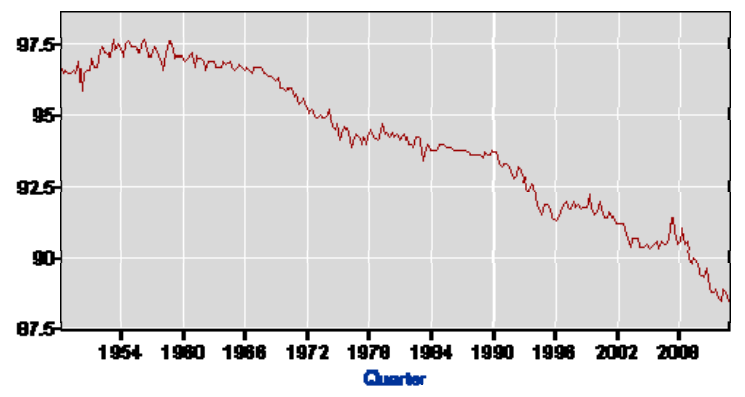

Figure 3. Labor force participation rates: prime age men 25-54 years 1948-2012

Current Population Survey: bureau of labor statistics.

As output per capita falls with declining labor force participation, so does the rate of growth and the standard of living if not offset by gains in productivity. Beginning in the mid-1990s we witness rising labor force participation for men 55 years of age and older due, in part, to increased health and longevity, changes away from "defined benefit" pensions, and shrinking retiree health benefits (Van Zandweghe, 2012). Collectively, the withdraw from the labor market of prime age men and the rising participation rates of men over the age of 54 are important if they offset each other.

Schirle (2008) examines rising labor force participation of older men, focusing on the joint retirement decisions of husbands and wives which the author posits as an important factor in explaining this trend. The author 
hypothesizes that the increase in older married men's labor force participation is a result of the complementarity of husbands and wives' leisure time. Employing a bivariate probit model the author finds that up to one third of the increase in older men's labor force participation can be explained by working wives.

DiCecio et al. (2008) view changes in the rules governing Social Security Benefits as a major factor in older men remaining in the labor force longer than men of a generation earlier. Amendments in Social Security Rules in 1977 significantly reduced benefits for men turning 65 in 1982 and beyond. In 1983, another amendment increased the age at which retirees could draw full benefits from 65 to 66 years for those born after 1937 (Note 4). Other changes included a premium for delaying Social Security benefits each year up to the age of 70 and a slowdown in the growth of Social Security benefits (Note 5). The authors also point to the tendency of men over the age of 55 to continue working until the age of 65 to maintain employer sponsored health insurance at which time they qualify for Medicare.

Blau and Goldstein (2010) examine the effects of rules governing Social Security benefits and the labor force participation rate of older men beginning in the late 1990s. Their findings indicate that increases in the Full Retirement Age (FRA) and Delayed Retirement Credit (DRC) can explain one quarter to one half of the rise in labor force participation rate of men over the age of 54 years. Other factors include greater years of education and increased labor force participation of married women. Employing OLS estimates and focusing on Social Security variables, the authors find that changes in the rules governing FRA and DRC are the most important factor in the rise in the labor force participation of older men, explaining 25 to 50 percent of the increase, with 16 percent attributed to the increased labor force participation of married women (Note 6).

This article first describes changes in the labor force participation of men over the age of 54 years, focusing on human capital and demographic variables then reports estimates of their retirement decision. Section 2 presents a model of older men's retirement decision as a binary choice variable. Section 3 reports variable means from the sample extracted from the Panel Study of Income Dynamics. Section 4 presents the results of Maximum Likelihood Probit coefficient estimates. Section 5 provides a summary, conclusions, and suggestions for further research.

\section{Model}

Given the constraints imposed by the 24-hour day, the individual may engage in two activities, "Labor" defined as working in the market for a wage and "Leisure" represented by any non-market activity. The individual's utility function is maximized for some collection of commodities given his labor/leisure choice, personal characteristics, level of wealth, and individual preferences for the non-pecuniary benefits associated with labor. Hours worked are, of course, limited by the 24-hour day and by physical endurance. Nonetheless, we may assume the "standard work year" of 2,000 hours or 40 hours per week (Killingsworth, 1983). For individuals out of the labor force a corner solution exists with 24 hours of leisure per day. The retirement decision may be modeled as the demand for leisure, a function of both the wage rate and total income. Thus, given the individual's taste for leisure an increase in total income, holding wages constant, will result in an increase in the demand for leisure (income effect) while an increase in wages, holding total wealth constant, will decrease the demand for leisure (substitution effect). A closer examination of the labor/leisure decision of older men introduces additional considerations not generally associated with younger men. For example the labor/leisure decision for older men is formed by considering the maximum value of discounted utility of working versus withdrawing from the labor force. Further considerations include Social Security rules, regulations regarding pensions, the rate of return on investments, and net worth. The retirement decision can be modeled as a binary choice variable.

$$
\begin{aligned}
& \mathrm{W}^{\mathrm{m}}{ }_{i}-\mathrm{W}_{\mathrm{i}=0}^{\mathrm{r}}>0 \Rightarrow \mathrm{NLFP}=0 \\
& \mathrm{~W}^{\mathrm{m}}{ }_{\mathrm{i}}-\mathrm{W}^{\mathrm{r}}{ }_{\mathrm{i}=0} \leq 0 \Rightarrow \mathrm{NLFP}=1
\end{aligned}
$$

Where $\mathrm{W}^{\mathrm{m}}{ }_{i}$ is the estimated market wage or the value of time working in the market at the margin for individual $\mathrm{i}$, a man 55 years or older. $\mathrm{W}_{\mathrm{iH}=0}^{\mathrm{r}}$ is the marginal value of time for individual $\mathrm{i}$ or his reservation wage, the wage below which he will choose not to participate in the labor market; that is, he retires. Retired (Ret) is equal to 1 if the individual is retired and equal to zero if he continues to work, where NLFP is "non-labor force participation". The decision to retire can be modeled as a probit specification.

Assume that the difference between individual's market wage and reservation wage is a linear function of both observable characteristics and an unobservable random disturbance term. The model may be estimated by

$$
\mathrm{I}^{*}{ }_{\mathrm{t}} \mathrm{W}^{\mathrm{m}}{ }_{\mathrm{i}}-\mathrm{W}_{\mathrm{i} \mathrm{H}=0}^{\mathrm{r}}=\beta_{0}+\beta_{1} \mathrm{X}_{\mathrm{m}, \mathrm{i}}+\beta_{2} \mathrm{X}_{\mathrm{r}, \mathrm{i}}+\varepsilon_{\mathrm{i}}
$$


Where $X_{m, i}$ is a vector of observable characteristics, a function of the individual's market wage. Since wages are available only for men who are working I estimate the log hourly wage for all individuals in the sample, those working as well as those retired.

Table 1. OLS estimates logwages

\begin{tabular}{ll}
\hline Variable & Coefficient \\
\hline Constant & 8.9070 \\
& $(0.0012569)$ \\
AgeHd & $-4.062 \mathrm{E}-03^{* * *}$ \\
& $(1.2569 \mathrm{E}-03)$ \\
HdYrsEd & $9.93613 \mathrm{E}-02 * * *$ \\
& $(8.383 \mathrm{E}-04)$ \\
Married & $4.410573 \mathrm{E}-01^{* * *}$ \\
& $(3.48213 \mathrm{E}-02)$ \\
Union & $3.852876 \mathrm{E}-02^{* * *}$ \\
& $(4.60959 \mathrm{E}-02)$ \\
ColDeg & $1.833269 \mathrm{E}-01 * * *$ \\
& $(4.50508 \mathrm{E}-02)$ \\
PoorHeath & $3.59133 \mathrm{E}-02$ \\
& $(3.9763 \mathrm{E}-02)$ \\
RaceBk & $-2.609022 \mathrm{E}-01 * * *$ \\
& $(3.58436 \mathrm{E}-02)$ \\
Number & 3,934 \\
\hline
\end{tabular}

Binary dependent variable: Ln Wages.

***Significant at $1 \%$ or less.

Standard Error in parentheses.

Estimated log hourly wages for 2010 are included in $X_{m, i}$ to capture the effects of the marginal value of time. The variable "years of education" is included representing an investment in human capital having the effect not only of boosting lifetime earnings but also affecting the quality of work (Less physically demanding). The estimated coefficient on years of education cannot be determined a priori since years of education affects the retirement decision through both higher lifetime earnings, prompting the individual to retire earlier through the income effect (leisure is assumed to be normal good) and by raising the market wage, the cost of leisure, prompting the individual to retire later via the substitution effect (Note 7) (Fallick \& Pingle, 2006). A dummy variable for union membership is included to control for the effects of higher earnings and relatively better working conditions associated with jobs covered by a union contract and is hypothesized to be negative.

The vector $\mathrm{X}_{\mathrm{r}, \mathrm{I}}$ determines the individual's marginal value of time and includes a dummy variable for marital status since the assorted responsibilities associated with marriage increase the demand for money income thereby raising the opportunity cost of leisure. The decision to retire is assumed to be a joint decision made within the context of the family. A dummy variable is included if wife is retired. I hypothesize that older men are less likely to retire if their wives are working, given a more pronounced complementarity of husbands' and wives' leisure time (Note 8). A dummy variable is included if the individual resides in a metropolitan area with a population of 1 million or more to control for the effect of higher incomes associated with large cities and their surrounding areas. To control for labor market discrimination a dummy variable for race (Black) is included in $\mathrm{X}_{\mathrm{r}, \mathrm{i}}$. A dummy variable for race (Black) is included to control for the possibility of labor market discrimination and is hypothesized to be negative. Another dummy variable is included to control for the effects of employer sponsored pension plans on the decision to retire. The random error term $\varepsilon_{\mathrm{i}}$ is assumed to be normally distributed 
with mean zero and variance $=1$. The parameter coefficients in Equation (2) are estimated using a Maximum Likelihood Probit model.

\section{Data}

Data files are obtainedfrom the Panel Study of Income Dynamics Main Family Data for year 2011 (Note 9). "Labor force participation" is defined as working for pay, seeking employment, or temporarily laid off. "Retired" is a self reported response to a question regarding labor force status (Note 9). The sample consists of more than 1,644 men, heads of households, 55 years of age or older who were not on Social Security Disability Insurance during the sampling year.

Table 2 reports variable means for both working and retired men segregated by three distinct cohorts, those 55 years or older, those between the ages of 55 and 65 (early retirement), and those between the ages of 66 and 69 years (full retirement) since Social Security Rules regarding benefit eligibility depend on the age at which an individual can begin drawing on benefits (Note 10).

Table 2. Sample means for year 2011

\begin{tabular}{lllllll}
\hline Age & $\geq 55 \mathrm{yrs}$ & & $\geq 55-65 \mathrm{yrs}$ & & $\geq 66-69 \mathrm{yrs}$ \\
\%Retired & Retired & Working & Retired & Working & Retired & Working \\
& $\mathbf{4 2}$ & $\mathbf{5 8}$ & $\mathbf{2 2}$ & $\mathbf{7 8}$ & $\mathbf{6 2}$ & $\mathbf{3 8}$ \\
AgeHd & $(0494)$ & & $(0.414)$ & & $(0.486)$ & \\
& $\mathbf{7 0 . 7 3}$ & $\mathbf{6 0 . 5 0}$ & $\mathbf{6 1 . 5 3}$ & $\mathbf{5 8 . 9 2}$ & $\mathbf{6 3 . 6 7}$ & $\mathbf{6 9 . 5 8}$ \\
EstWgSal & $(8.90)$ & $(5.24)$ & $(2.86)$ & $(2.84)$ & $(3.67)$ & $(3.56)$ \\
& $\mathbf{2 1 . 2 1}$ & $\mathbf{2 2 . 3 7}$ & 22.64 & 22.47 & $\mathbf{2 1 . 2 9}$ & $\mathbf{2 2 . 1 9}$ \\
HdYrsEd & $(3.41)$ & $(3.15)$ & $(2.74)$ & $(3.07)$ & $(3.30)$ & $(3.25)$ \\
& $\mathbf{1 3 . 1 7}$ & $\mathbf{1 3 . 5 4}$ & 13.90 & 13.56 & 12.88 & 13.64 \\
\%Married & $(3.16)$ & $(3.09)$ & $(2.67)$ & $(3.02)$ & $(3.26)$ & $(3.21)$ \\
& $\mathbf{7 8 . 9}$ & 81.2 & 79.9 & 80.5 & 82.2 & 90.3 \\
\%WfRetired & $(0.411)$ & $(0.391)$ & $(0.401)$ & $(0.396)$ & $(0.384)$ & $(0.298)$ \\
& $\mathbf{4 9 . 5}$ & $\mathbf{1 3 . 4 0}$ & $\mathbf{3 5 . 1}$ & $\mathbf{1 1 . 0}$ & $\mathbf{5 2 . 6}$ & $\mathbf{2 9 . 2 3}$ \\
\%AllWfs* & $(0.500)$ & $(0.341)$ & $(0.478)$ & $(0.313)$ & $(0.502)$ & $(0.458)$ \\
& 28.25 & & 16.28 & & 40.95 & \\
\%RaceBlk & $(0.450)$ & & $(0.369)$ & & $(0.493)$ & \\
& $\mathbf{1 7 . 3}$ & $\mathbf{2 3 . 0}$ & $\mathbf{8 . 3 3}$ & $\mathbf{2 4 . 7}$ & 15.3 & 8.3 \\
\%LgMetArea & $(0.379)$ & $(0.421)$ & $(0.278)$ & $(0.432)$ & $(0.361)$ & $(0.278)$ \\
& $\mathbf{3 4 . 8}$ & $\mathbf{4 2 . 8}$ & $\mathbf{3 6 . 4}$ & $\mathbf{4 3 . 3}$ & 31.4 & $\mathbf{3 8 . 9}$ \\
Number & $(0.477)$ & $(0.495)$ & $(0.482)$ & $(0.496)$ & $(0.466)$ & $(0.491)$ \\
& 688 & 956 & 236 & 834 & 116 & 70 \\
\hline
\end{tabular}

Significant differences at $10 \%$ or less in Bold.

*Retired+Working.

(Standard Deviation).

Turning first to all men 55 years or older, 42 percent are retired. Yet closer examination reveals that men under 66 years of age, that is, those who retire before eligibility for full Social Security benefits, 22 percent are retired. For men between the ages of 66 and 69 there is almost a three-fold increase in the percentretired, compared to early retirees, highlighting the relationship between the decision to retire and the age at which one may collect full Social Security benefits. There is no significant difference in estimated earnings and work status among the 55 to 65 age cohorts (Note 11). A greater percentage of men 66 years or older are married and compared with the entire sample. 
For men who retire before the age of full Social Security benefits, 16 percent of their wives are retired compared to men who retire at 66 or older where 41 percent of their wives are retired thereby reinforcing the complementarity of leisure time among husbands and wives. Average years of education are a decreasing function of age with retired men 65 years or younger attaining almost one-half year more of education than men 66-69 years of age (For all men over the age of 69 average years of education is 12.74). As expected, the retirement decision is an increasing function of age.

\section{Results}

Maximum Likelihood Probit coefficient estimates and marginal effects for three distinct age cohorts; 55 years and older, 55 through 65 years, and 66 through 69 years are presented in Table 3.

Table 3. Maximum likelihood probit estimates: older men

\begin{tabular}{|c|c|c|c|}
\hline Variable & $\begin{array}{l}\text { Age } \geq 55 \\
\text { Coefficient }\end{array}$ & $\begin{array}{l}\text { Age } \geq 55 \& \leq 65 \\
\text { Coefficient }\end{array}$ & $\begin{array}{l}\text { Age } \geq 65 \& \leq 69 \\
\text { Coefficient }\end{array}$ \\
\hline \multirow[t]{2}{*}{ Constant } & $11.4826^{* * *}$ & $25.66 * * *$ & 18.004 \\
\hline & $(0.771)$ & $(0.2800)$ & $(9.418)$ \\
\hline \multirow[t]{3}{*}{ EstLgWg } & $-1.390 * * *$ & $-3.1200 * * *$ & $-2.0560^{*}$ \\
\hline & $(0.0853)$ & $(0.3282)$ & (1.1494) \\
\hline & $\dagger-0.5502$ & $\dagger-0.7919$ & $\dagger-0.7365$ \\
\hline \multirow[t]{3}{*}{ HdYrsEd } & $1.400 * * *$ & $3.1247 * * *$ & $2.0324 *$ \\
\hline & $(0.0356)$ & $(0.3300)$ & $(1.1462)$ \\
\hline & $\dagger 0.545$ & $\dagger 0.7977$ & $\dagger 0.7267$ \\
\hline \multirow[t]{3}{*}{ Married } & $0.3122 * * *$ & $0.9635^{* * *}$ & -0.1421 \\
\hline & $(0.1021)$ & $(0.1649)$ & $(0.5225)$ \\
\hline & $\dagger 0.1235$ & $\dagger 0.1803$ & $\dagger-0.0450$ \\
\hline \multirow[t]{3}{*}{ LgMetArea } & 0.0766 & $0.3644 * * *$ & 0.2278 \\
\hline & $(0.3177)$ & $(0.1100)$ & $(0.2805)$ \\
\hline & $\dagger 0.0364$ & $\dagger 0.0952$ & $\dagger 0.0798$ \\
\hline \multirow[t]{3}{*}{ WfRet } & $0.7120 * * *$ & $0.6285^{* * *}$ & $0.7194 * * *$ \\
\hline & $(0.0930)$ & $(0.1258)$ & $(0.2247)$ \\
\hline & $\dagger 0.2987$ & $\dagger 0.1906$ & $\dagger 0.2429$ \\
\hline \multirow[t]{3}{*}{ Union } & $-0.9246 * * *$ & -0.1617 & \\
\hline & $(0.2589)$ & $(0.2888)$ & \\
\hline & $\dagger-0.3074$ & $\dagger-0.0385$ & \\
\hline \multirow[t]{3}{*}{ RaceBk } & $-0.2799 * * *$ & $-0.7812 * * *$ & 0.1827 \\
\hline & $(0.0962)$ & $(0.1468)$ & $(0.5516)$ \\
\hline & $\dagger-0.1131$ & $\dagger 0.1617$ & $\dagger 0.0630$ \\
\hline Number & 1,644 & 1,070 & 177 \\
\hline Pseudo $\mathrm{R}^{2}$ & 0.3345 & 0.1669 & 0.1025 \\
\hline
\end{tabular}

Binary dependent variable: Retired $=1$, zero otherwise.

***Significant at $1 \%$ or less.

*Significant at $10 \%$ or less.

Standard Error in parentheses.

$\dagger$ Marginal effects are the change in the probability of non-participation being limited for a one-unit change in the corresponding independent variable computed at the mean of the independent variables. 
Turning first to the total sample, all variable coefficients are significant with the exception of the variable controlling for residing in a large metropolitan area (Note 12). As anticipated, coefficient estimates on earnings (the opportunity cost of leisure) are negative and significant. The largest (marginal) effect on the decision to retire amongst men in the entire sample are Years of Education (+0.545), Union Membership (-0.3074), and Wife Retired $(+0.2978)$. Since the focus here is on older men's decision to retire earlier, probit estimates are presented for men age 55 through 65 (i.e., those ineligible for full Social Security Benefits) and for men 66 through 69 years (i.e., those eligible for full benefits) (Note 13). The largest marginal effects on their retirement decision for men who retire before full Social Security eligibility are estimated earnings (-) and years of education $(+)$. The marginal effect on earnings is negative and greatest for those below full retirement age. Years of education has a large, positive effect on the decision to retire with the greatest effect on men who choose to retire before attaining the age of full Social Security benefits (55-65 years) with each additional year of education increasing the probability of retirement by 0.798 (Note 14). One may hypothesize that men with greater years of education earn higher incomes, allowing them to accumulate greater wealth so that the income effect on the decision to retire (positive) is greater than the substitution effect (negative). This hypothesized relation is reinforced when one examines the respondent's wealth. Men with at least a Baccalaureate degree possess wealth more than 2 times greater than men without a Baccalaureate degree, $\$ 1.03$ million compared to $\$ 0.332$ million (Note 15). The effects of marriage on the decision to retire differ by age cohort. For the entire sample and for men below the age of 66 years the marginal effects of marriage are positive; yet, for men 66 to 69 years of age the estimated coefficient is negative. The effects of a wife's decision to retire on her husband's retirement decision is positive and significant for all age cohorts, increasing the probability of retiring for men 55 to 65 and for men 66 to 69 years of age 0.19 and 0.25 respectively reinforcing Schirle' (2008) hypothesis regarding the complementarity of husband's and wives' leisure time (Note 16). The coefficient estimate on race (Black) is positive and significant for the entire sample and for early retirees aged 55 to 65 years.

Since the focus here is on the retirement decision of older men, I take as given that the effects of changes in Social Security Benefit rules has been assimilated into the retirement decision of the population. With more than 80 percent of respondents born after 1954, further increases in the retirement age are likely to arise from other factors, specifically greater years of education and the retirement decision of wives (Note 17). Table 4 presents the results of "Counterfactual Simulations" to underscore the effects of years of education and the percentage of retired wives on an older man's decision to retire.

Table 4 provides Actual and Predicted rates of retirement for 3 distinct cohorts; that is, for the entire population-men 55 years of age or older, men between the ages of 55 and 65 years and men between the ages of 66 and 69 years. By substituting mean years of education for men over the age of 55 in 2011 (13.36 years) with means years of education for men over 55 in 1990 (10.42 years); that is, with mean years of education for men a generation older, predicted probabilities fall by approximately one-third within each age cohort. The importance of greater years of education and its effect on the decision to retire will likely continue, lowering the age of retirement as average years of education rise for younger cohorts. Given thataggregate labor force participation rates have fallen since the mid-1990s, results reported here indicate that rising average years of education will reinforce, at least in part, this trend.

Table 4. "Counterfactual" simulations to explain increase in labor force participation rates

\begin{tabular}{lllll}
\hline Cohort & Actual & Predicted & $\begin{array}{l}\text { Mean Yrs. Ed } \\
10.42(1990)\end{array}$ & $\begin{array}{l}\text { Wife Retired } \\
14.27 \%(1990)\end{array}$ \\
\hline Age $\geq 55$ & 0.4455 & 0.4237 & 0.1366 & 0.3948 \\
Age $\geq 55 \& \leq 65$ & 0.2389 & 0.2357 & 0.0698 & 0.2298 \\
Age $\geq 66 \& \leq 69$ & 0.6214 & 0.5132 & 0.1642 & 0.4461 \\
\hline
\end{tabular}

Schirle (2008) suggests the increase in wives' labor force participation rates and their retirement decisions affect a husband's decision to retire, given the complementarity of husbands' and wives' leisure time. Table 4 also reports changes in predicted probability of retirement if the percent of retired wives, 23.70 percent in 2011 is substituted for the percentof retired wives in 1990, 14.27 percent. For the entire sample (men over the age of 55 years), predicted probabilities decline by almost 3 percent with the greatest decline for men between the ages of 
66 and 69 years, 6.7 percent. For men who retire before eligibility for full Social Security retirement benefits, predicted probability of retirement remains basically constant.

\section{Summary and Conclusions}

The effects of changes in Social Security Benefit rules that began over 30 years ago is a significant factor in explainingthe trend of rising retirement age among older men. Yet these changes are assumed to have been completely assimilated into the retirement decisions of men in this sample. The focus in the above has been on additional factors that contribute to the trend for older men to forestall retirement. Maximum Likelihood Probit coefficient estimates for three distinct age cohorts verify the hypothesized effects of determinants on the decision to retire. Specifically, the coefficient on estimated earnings is negative and is the largest marginal effect on the decision to retire followed by years of education $(+)$ and wife retired $(+)$. One may ask; can the increase in older men's labor force participation rates compensate for the withdraw from the labor force of prime age men and moderate the deleterious effects of a shrinking labor force on economic growth? The results reported here can offer some insight into this question. The effects of wives' retirement decision will likely continue to forestall the retirement decision of their husbands as more married women reach retirement age. Yet the combined effects of greater years of education $(+)$ and the consequent increase in earnings associated with investment in human capital (-) cannot be determined a priori. One may speculate that the rise in labor force participation rates of older men will offset rather than reverse the decline in men's labor force participation rates that began more than a half century ago. Further research can identify additional changes in labor force participation of older men as the age required for full Social Security Benefits continues to rise.

\section{References}

Aaronson, S., Pringle, B., Figura, A., Pringle, B., \& Wascher, W. (2006). The Recent Decline in the Labor Force Participation Rates and Its Implication for Potential Labor Supply. Brookings Papers on Economic Activity, 1, 69-134. http://dx.doi.org/10.1353/eca.2006.0012

Blau, D., \& Goldstein, R. M. (2010). Can Social Security Explain Trends in Labor Force Participation of Older Men in the United States? The Journal of Human Resources, 45(2), 328-363. http://dx.doi.org/10.3368/jhr.45.2.328

DiCecio, R., Engemann, K. M., Owyang, M. T., \& Wheeler, C. H. (2008). Changing Trends in the Labor Force: A Survey. The Federal Reserve Bank of St. Louis Review, 47-62.

Fallick, B., \& Pingle, J. (2006). A Cohort-Based Model of Labor Force Participation. Federal Reserve Bank Washington D.C., 1-53. http://dx.doi.org/10.1017/CBO9780511572104

Killingsworth, M. R. (1983). Labor Supply. Cambridge: Cambridge University Press.

Panel Study of Income Dynamics. (2011). Public use dataset. Retrieved from http://psidonline.isr.umich.edu

Schirle, T. (2008). Why Have the Labor Force Participation Rates of Older Men Increased since the Mid-1990s? Journal of Labor Economics, 26(4), 549-594. http://dx.doi.org/10.1086/589457

Slusher, C. (1998). Pension Integration and Social Security Reform. Social Security Bulletin, 61(2), 2.

Social Security Administration. (2014). Retrieved from http://www.ssa.gov/retirement/1943.html

U.S. Department of Health \& Human Services, Administration of Aging. (2014). Projected Future Growth of the Older Population. Retrieved from http://www.aoa.gov

U.S. Department of Labor, Bureau of Labor Statistics. (2014). Retrieved fromhttp://www.bls.gov/data\#employment

Van Zandweghe, W. (2012). Interpreting the Recent Decline in Labor Force Participation. Economic Review, 5-34.

\section{Notes}

Note 1. The Bureau of Labor Statistics defines the labor force participation rate as the proportion of civilian, non-institutionalized population 16 years or older who are either working or seeking employment.

Note 2. The labor force participation rate of women had been rising for over a century, accelerating in the 1970s. It peaked at 60 percent in 1999 and stands at around 57 percent in 2013. 
Note 3. The Revenue Act of 1942 expressly prohibited employers from discriminating in favor of management, supervisors, and high-income employees thus preventing employers from providing pensions only to favored employees while excluding others to save on taxes.

Note 4. For those born between 1938 and 1942 eligibility increased by 2 months each year until 1943. Those born between the years 1943 and 1954 must wait until the age of 66 to receive full Social Security benefits.

Note 5. Between 1965 and 1984 benefits increased by 88 percent compared to 23 percent between 1985 and 2005.

Note 6. The authors do not discuss some shortcomings of OLS estimates and discrete choice models. Specifically OLS predicted coefficients may fall outside of range of the interval (1-0). A probit regression model would likely produce more robust estimates.

Note 7. Years of education not only increase the expected market wage but also represent a foundation for jobs with higher social status. We may also view additional years of education as signifying both the individual's natural aptitude as well as his taste for labor over leisure.

Note 8. Schirle (2008) notes that the labor force participation rates of older women increased by 7 percent between 1994 and 2005.

Note 9. This was the most recent data available from PSID at the time of writing.

Note 10. The respondent is asked if he is "Working now", "Only temporarily laid off", "Looking for work", "Retired", "Permanently disabled", "Keeping house", or "Student".

Note 11. A 1983 amendment increased the age of eligibility for full Social Security Benefits from 65 to 66 years for those born after 1942. An individual may begin receiving Social Security benefits at the age of 62 but at a reduced rate of 75 percent of full benefits. Benefits increase at a rate of between 5 to 7 percent per year until the age of 66 at which time the individual is entitled to 100 percent of benefits. These changes in Social Security Rules, of themselves, can explain why men are retiring later since the "return" on Social Security benefits after the age of 66 increases at a rate equal to or better than investment in financial instruments. One obvious risk of deferring benefits is, of course, mortality.

Note12. Blau et al. (2010) assume earnings are a proxy for accumulated lifetime wealth.

Note 13. A dummy variable for men born before 1943 was included to control for the effects of changes in Social Security eligibility rules but was not significant for any cohort.

Note 14 . An individual who choses to retire at age 62 will receive 75 percent of full monthly benefits. At age 65 he will receive 93.3 percent of his full benefits.

Note 15. Blau and Goldstein (2010), controlling for "High School", "Some College", and "College" also find coefficient estimates positive. Schirle (2008) likewise finds men with greater years of education tend to retire earlier.

Note 16. Blau and Goldstein (2010) note one reason for greater labor force participation of older men is the "rapid replacement" of relatively lower participating high school graduates with higher participating college graduates.

Note 17. An interaction term for married men with retired wives was not significant for any of the age cohorts.

Note 18. The age at which one may apply for full Social Security Benefits will increase to 67 years in 2022.

\section{Copyrights}

Copyright for this article is retained by the author(s), with first publication rights granted to the journal.

This is an open-access article distributed under the terms and conditions of the Creative Commons Attribution license (http://creativecommons.org/licenses/by/3.0/). 